\title{
Transformational Leadership and Job Satisfaction In the Saudi Arabian Technical Colleges ${ }^{*}$
}

\author{
Mansour Abdullah Al-miman \\ Department of Management Technology \\ Jeddah College of Technology \\ Jeddah - Saudi Arabia
}

\begin{abstract}
:
The purpose of this descriptive and cross-sectional analysis is to study leadership profiles of the heads of technical departments in technical colleges in the western region of Saudi Arabia, and explore the relationship between department heads' transformational leadership behaviours, trainers' job satisfaction, and some demographic variables. The data were collected through the distribution of one questionnaire among 357 trainers in the five technical colleges in the western region of Saudi Arabia. Three instruments were used in the questionnaire: the Roueche, Baker and Rose (1989) model to assess department chair transformational leadership behaviours; the Mohrman, Cooke, Mohrman, Duncan and Zaltman (1977) model of Morhman-Cooke-Morhman Job Satisfaction Scale (MCMJSS); and a demographic segment. The results shows that the dominant transformational behaviour was (value), with a mean score of 3.89, while (Motivation) was perceived as the weakest of the transformational behaviours with a mean score of 3.75. The analysis support relationship between department heads perceived transformational and college trainers' job satisfaction.
\end{abstract}

\section{Introduction}

The Saudi Arabian technical and vocational training system is passing though a period of transformation. Since 2005, the Technical and Vocational Training Cooperation (TVTC) has been working on a comprehensive technical and vocational reform programme. One of the aims of this reform programme is to strengthen technical and vocational management. However, human resource management is still not what it should be, and the human aspects relating to trainers' satisfaction, which affects productivity, are inevitably neglected. As well, in the TVTC, leadership is still in its infancy. There has been little research related to this subject particularly in the technical and vocational training.

Therefore, this research with its aim of investigating technical college trainers' perceptions of transformational leadership behaviours of department heads, and examining the relationship between heads of departments' transformational leadership and trainers' job satisfaction in Western region of Saudi Arabia, is an important step toward technical colleges' effectiveness and increased efficiency. The results of this research will allow a better understanding of the relationship between transformational leadership and trainers'job satisfaction.

It is anticipated that a better understanding of these issues and their relationships can aid further research and pinpoint better strategies for recruiting, promotion and training of future department chairs and trainers.

* This Research was Submitted in June 2010, and Accepted for Publishing in September 2011. 
As Leithwood, Jantzi, and Steinbach (2000 b) affirmed, "Transformational leadership is a powerful stimulant to improvement" (p.37). Transformational leadership involves the strategic elements such as direction setting, developing people and redesigning the organization (Gunter, 2001). Department chairs are unique from other higher education administrators because of their direct role in curriculum development, department development, and the expectation that they remain current in their disciplines in terms of research and teaching while executing a myriad of administrative functions (Gmelch \& Miskin, 2004; Whitsett, 2007). Transformational leadership has become an accepted model of instruction and training in college and university preparation programs, and is substantiated by a body of evidence that supports its contribution to the development of capacity and commitment (Bogler, 2001; Leithwood \& Jantzi, 1999). Within the technical training context, the department heads when they act as transformational leaders are responding to multiple drivers for change, transformational leadership has been associated with effective leaders (Griffith, 2004).

Several studies demonstrated that transformational leader behaviours are positively related to employees' satisfaction, self-reported effort, commitment, motivation and job performance (Avolio \& Bass, 1988; Conger \& Kanungo, 1987; House, Spangler, \& Woycke, 1991; Griffith, 2004).

\section{Literature review:}

\section{Transformational leadership:}

The subject of leadership is of great interest to businesses, as well as to technical and vocational training facilities. In the past several decades, management experts have undergone a revolution in how they define leadership. They have gone from a very classical, autocratic approach to a more creative and participative approach. It appears in the management literature that there are several styles of leadership, such as autocratic, bureaucratic, laissez-faire, charismatic, democratic, participative, situational and transactional. However, the continued search for good leaders has resulted in the development of many leadership theories. One leadership theory that has gained recent and widespread attention is the transformational leadership, which was initiated by Burns (1978). The popularity and attractiveness of this leadership style stems, at least in part, from its consistent association with superior performance in various organisations, such as business (Barling, Weber \& Kelloway, 1996). Burns's model was based on the premise that transforming leadership raises both leaders' and subordinates' levels of motivation and morale. When transformational leadership causes more active behaviour of all participants, due to inner motivation, the transactional leaders try to motivate subordinates by rewarding or punishing them (Burns, 1978).

Recent studies of transformational leadership have been focused on the development and training of transformational leadership, specific areas within it, as well as testing and developing of its measurements. Since Burns, several researchers have studied and defined transformational leadership (Bass, 1985; Bennis \& Nanus, 1985; Kouzes \& Posner, 1988; Tichy \& Devanna, 1990; Avolio, 2005; Luthans \& Avolio, 2003), and some have operationalised the concept (Bass and Avolio, 1990a; Kouzes and Posner, 1988; Roush, 1992).

Bass's (1985) definition of the relationship between transformational leader and subordinate included charisma (or idealised influence), inspirational leadership, individualised 
consideration and intellectual stimulation. Kouzes and Posner's (1988) view was predominantly based on trust. If a leader is perceived by subordinates to be reliable, the subordinates will participate to gain the common vision. Kouzes and Posner (1988) discovered that executives who persuaded others to join them followed that same path: the vision-involvement-persistence (VIP) model. The more specific dynamics of this model consist of five parts: challenging the process, inspiring a shared vision, enabling others to act, modelling the way and encouraging the heart (Kouzes and Posner, 1988).

Tichy and Devanna's (1990) definition of transformational leadership was concerned with change, innovation and entrepreneurship. According to them, transformational leadership is processed through recognising the need for revitalisation, creating a new vision and institutionalising change. Avolio (2005) and Luthans and Avolio, (2003) established four interrelated behaviours that constitute transformational leaders. First, department heads can provide inspirational maturation; second, intellectual stimulation, which is fostered by questioning current strategies, posing problems from various perspectives and supporting new procedures for work; third, idealised influence; and finally, individualised consideration.

Several instruments have been developed to measure transformational leadership. These include: the multifactor leadership questionnaire (MLQ) by Bass and Avolio (1990b); the leadership behaviour questionnaire (LBQ) by Sashkin and Burke (1992); the leadership description questionnaire (LDQ) by Clover and Rosenbach (1986); the leadership report (LR) by Burke (1988) (Sashkin \& Burke, 1992); the leadership feedback questionnaire (LFQ) by Roush (1992); the transformational leadership questionnaire (TLQ-LGV) by Alban-Metcalfe and Alimo-Metcalfe (2000); and the leadership practices inventory (LPI) by Kouzes and Posner (1988).

Some of the instruments measure both transformational and transactional leadership (Bass \& Avolio, 1990a), and some focus only on transformational leadership (Roueche et al., 1989; Kouzes \& Posner, 1988). Roueche and his colleagues established a model of transformational leadership behaviour in a higher education setting that consists of five themes: vision, influence orientation, motivation orientation, people orientation and values orientation. First, vision refers to the leader's ability to articulate a clear concept of the future to others, and to work toward developing a shared understanding of the goals of the organisation. Chairs may be able to use the vision theme to influence faculty toward a future where flexibility and innovation are the operational norm. Second, influence orientation, where chairs may employ the influence orientation theme to gain commitment from faculty as the department engages in participative decision-making and problem-solving. Third, motivation orientation is the process by which team members accept a new mission and vision, and are excited by performance. Chairs may use the motivation orientation theme to sustain their vision, as rewards are reaped due to increased success. Fourth, people orientation refers to the leader's ability to recognise the strengths of individual team members and to develop them. Chairs may employ the people orientation concept as they identify the strengths and weaknesses of individual faculty members, develop their competencies and then align them with the department's goals. Fifth, values orientation is viewed as an ethical dimension of morally acceptable and uplifting behaviour for followers, and constitutes the moral fibre of the leader to include commitment, quality, integrity, trust and respect. These ive themes represent a spectrum of transformational leadership behaviours that may be applicable to the leader role of department chairs (Roueche et al., 1989). 
Gittens (2009) found that all themes associated with the Roueche, et al. (1989) model were a good conceptual fit to the leader role of chairs. He concluded that by examining the applicability of behaviours associated with the Roueche et al. (1989) model of transformational leadership, his study provided insights into the expectations of chairs' leadership roles from faculty and department chairs. Gittens recommended for further research that these expectations be used for selection, evaluation and professional development of chairs. He concluded that the current challenges in higher education require effective leadership at every level, including department chairs. He also concluded that the Roueche et al. (1989) model of transformational leadership may provide an appropriate lens for examining departmental leadership, and once that transformational leadership model for chairs has been developed and the Multifactor College Leadership Questionnaire IIIDepartment Chair Version (MCLQ-III-dc) has been refined, further research studies that correlate the relationship between chairs' transformational leadership behaviour and measures of organisational effectiveness would provide further validation of the model. If the relationship is positive, then the model could be used as a basis for professional development programmes, including orientation and leadership coaching for chairs

In summary, the transformational leader articulates the vision in a clear and appealing manner, explains how to attain the vision, acts confidently and optimistically, expresses confidence in the followers, emphasises values with symbolic actions, leads by example, and empowers followers to achieve the vision (Yukl, 2002).

\section{Job satisfaction:}

Methodologically, we can define job satisfaction as an employee's affective reaction to a job, based on a comparison between actual outcomes and desired outcomes. It encompasses specific aspects of satisfaction related to pay, benefits, promotion, work conditions, supervision, organisational practices and relationships with co-workers (Misener, Haddock, Gleaton \& Ajamieh, 1996). Job satisfaction is generally viewed as the attitude of the worker toward the job (Roberts, 2001). Research findings indicated that teachers could be satisfied when they were involved in formulation of the goals, given autonomy, valued as professionals, and respected (Hall, 1994). Lipham (1981) studied the faculties of four secondary schools and concluded that staff involvement and perceptions of principal leadership were positively related to job satisfaction. Hoy and Miskel (1982) explained that the quality of teacher and administrator relationships and the quality of leadership correlated highly with teacher job satisfaction: "the better the relationship and the better the quality of leadership, the higher teacher morale tends to be"(p.338). Hoy and Miskel (1982) reported that teachers' participation in decision making increased their morale and enhanced their job satisfaction. Holdaway (1978) asserted that the teachers' lack of opportunity to participate in decision making appeared to be the most powerful source of teacher dissatisfaction. The studies of leadership and the effects on teacher job satisfaction have shown the behavior of the leader to be an important factor in group effectiveness. Mohrman, Cooke, and Mohrman (1978) studied participation in decision making in educational settings, and found that teacher participation in decisions could improve job satisfaction. Stogdill (1974), in an earlier study, concluded that strong, democratic leadership was positively related to group member satisfaction. Researchers (Fowler, 1991; Gallmeier, 1992) have concluded that leadership and teacher performance have a strong relationship. 


\section{The prospected role of technical department heads:}

Gmelch and Miskin (2004) conducted a study of more than 800 chairs from colleges and universities across the United States, to identify their most important tasks that are critical to department productivity and survival. As a leader concerned primarily with setting a longterm vision and addressing issues external to the department, it is crucial to address current challenges in higher education. The leader role of chairs positions them to advance fiscal and resource administration and curriculum development (Wergin, 2004; Jones, 2006), which addresses the challenges, and more specifically, the challenges in the academic department where they are expected to provide leadership in the change process within higher education institutions (Czech, 2007; Gmelch \& Miskin, 2004).

Falk and Smith (2003) emphasised that individual vocational education leaders must be able to respond to internal and external change through their character attributes. The ability to raise follower commitment and motivation is essential for a transformational leader to accomplish change, especially in uncertain times (Leithwood \& Jantzi, 1999; Marks \& Printy, 2003). Transformational leadership relies on the ability of the leader to inspire followers through the creation and dissemination of a vision (Bottery, 2001).

Avolio and Yammarino (2002) explained that transformational leaders focus on vision, ideals, values, risks and change. Transforming leaders are known for their ability to motivate and energise followers into a common vision (Krill, Carter \& Williams, 1997). Roueche et al. (1989) found that vision appeared to be the main catalytic component that allowed transformational leaders to be successful. Transformational leaders are able to affect individuals, because such leaders provide a vision, communicate high expectations, provide intellectual stimulation, provide support and consideration, role model behaviour, take risks, show integrity, and inspire followers to create change (Bass, 1990; Hay, 2006; Kezar, Carducci \& Contreras-McGavin, 2006).

\section{Methodology:}

The purpose of this study was to determine if there was a relationship between perceived transformational leadership behaviours of department heads and trainers' expressed job satisfaction in their current position. Specifically, this study examined the perceptions of trainers in technical colleges in the western region of Saudi Arabia regarding the leadership

styles of their department heads and the trainers' own job satisfaction levels. This part presents the survey response rates, the demographic data and the research findings. Specific research questions addressed are as follows:

- What are the perceived transformational leadership behaviours of department heads (in regard to the five themes of Roueche et al., 1989), model of transformational leadership (vision, influence orientation, motivation orientation, people orientation and values orientation)?

- What is the relationship between department heads' transformational leadership behaviours, trainers' job satisfaction and the demographic variables?

Implications for the identification, selection, and training of individuals for the department heads's role in the TVTC college's departments should be evident from the study. 


\section{Sample and data collection:}

The study utilised descriptive correlation design and cross-sectional survey methodology. The Technical and Vocational Training Corporation, TVTC is a national and governmental corporation run by the Saudi Ministry of Labour. It includes over than 40 colleges in addition to the training centers and the technical institutes. The Western Region (Makkah) consists of five colleges: Jeddah College of Technology, Jeddah College of Communications Technology, Makkah, Al-Taif, and Al Qunfeza Colleges of Technology. The term, (TVTC colleges-western region) is used in this study to correspond to those colleges. The technical college setting for this study included all the five technical colleges in the western region of Saudi Arabia: Jeddah College of Technology (JCT), Jeddah College of Communications Technology (JCCT), Makkah College of Technology (MCT), Al-Taif College of Technology (TCT) and Al-Qunfeza College of Technology (QCT).

TVTC has set up a number of important objectives that are to be achieved in near future, one of those is to contribute in halting the movement of citizens to big cities (e.g. Jeddah and Makkah) by opening new technical training centers in all Kingdom's regions (TVTC website), this objective can be achieved by the qualified, innovative, and creative administration to run these new training centers successfully, as the western region cities (Jeddah and Makkah) are considered the most important cities in the social and economic progress plans in Saudi Arabia TVTC developed action plans to manage changes and to build strong and sustainable organizations for the future (TVTC website), in order to achieve that it requires an extensive range of management and leadership capabilities especially at the managerial and supervisory levels, to meet the continued challenges for change and innovations. Successful organisations that change readily and successfully need staff at all levels who feel that they have the leadership capabilities in order to stay innovative and competitive, full realization of human potential in technical responsibilities is critical to human development and the social and economic progress (Copa and Plihal, 1996). The future of technical education requires solutions that are flexible, creative, and innovative to address issues of access, curriculum quality, affordability, and the use of technology in education, according to experts on (Jones, 2006; Miller \& Oldham, 2006; Wellman, 2006).

At the time of the study, these colleges employed 683 full-time trainers, and a random sample of 500 vocational college trainers were selected from the population of $n=683$. At the time of the study, the researcher occupied the Dean post of JCT; the questionnaires were emailed to the department heads in JCT and mailed to the other four college's deans to coordinate the survey procedures. The department heads of the five colleges were then responsible for distributing the questionnaires to the trainers. Technical Trainers were randomly selected from different technical training departments in the five Technical colleges e.g., Departments of Electrical Technology, Mechanical Technology, Civil and Architectural Technology, in addition to Departments of Tourism and Hotels department, Administration Technology, and General Studies Centre.

The mailing consisted of the questionnaire and a cover letter. The letter gave directions on how to complete the questionnaire and return it. It also explained the purpose of the study, assured the subjects of anonymity and encouraged their participation. Subjects were asked to respond to the questionnaires and return them to the researcher within two weeks. At an interval of one week apart, an e-mail message was sent to the colleges' deans and department heads to remind respondents to complete and return the instrument. A follow-up reminder e- 
mail and another attached copy of the questionnaire were then sent two weeks after the initial mail-out to department heads who had not returned their survey.

A total of 366 of the 500 questionnaires were returned, which represented a response rate of $73.2 \%$. Out of these 366 questionnaires, 357 were usable and deemed suitable to be analysed. From Jeddah College of Technology (JCT) 147 usable questionnaires were received and (46) from Jeddah College of Communications Technology (JCCT), (49) from Makkah (MCT), (77) from Al-Taif TCT, and (38) usable questionnaires received from Al Qunfeza Colleges of Technology (QCT).

Table (1) is a summary of the characteristics of the sample. As shown in the table, the sample was comprised of individuals of varied demographic and organisational backgrounds. The respondents spanned a wide range of colleges. A majority of respondents were employed at JCT $41.2 \%$, while $55.2 \%$ had a graduate degree, $50.4 \%$ were 30 years of age or older, $52.1 \%$ had 11 years service or more, $52 \%$ and were of Saudi nationality.

Table (1)

Participants' demographic characteristics

\begin{tabular}{|c|c|c|}
\hline Characteristics & Frequency & Percent \\
\hline \multicolumn{3}{|l|}{ College } \\
\hline$\overline{\overline{\mathrm{TCT}}}$ & 77 & 21.6 \\
\hline JCCT & 46 & 12.9 \\
\hline QCT & 38 & 10.6 \\
\hline JCT & 147 & 41.2 \\
\hline MCT & 49 & 13.7 \\
\hline \multicolumn{3}{|l|}{$\overline{\overline{\text { Qualification }}}$} \\
\hline Diploma & $\overline{45}$ & 12.6 \\
\hline Graduate & 197 & 55.2 \\
\hline Master & 84 & 23.5 \\
\hline $\mathrm{PhD}$ & 31 & 8.7 \\
\hline \multicolumn{3}{|l|}{ Age } \\
\hline Less than 30 years & 63 & 17.7 \\
\hline $30-40$ years & 180 & 50.4 \\
\hline $41-50$ years & 76 & 21.3 \\
\hline 51 years and above & 38 & 10.6 \\
\hline \multicolumn{3}{|l|}{ Length of service } \\
\hline 1-10 years & 164 & 45.9 \\
\hline $11-20$ years & 123 & 34.5 \\
\hline 21 years and above & 70 & 19.6 \\
\hline \multicolumn{3}{|l|}{ Nationality } \\
\hline Saudi & 275 & $\overline{777.0}$ \\
\hline Other & 82 & 23.0 \\
\hline
\end{tabular}

\section{Instrumentations:}

The questionnaire consisted of three measures that were used for data collection:

1- Amodified version of the Multifactor College Leadership Questionnaire III- Department Chair Version (MCLQ-III-dc) adopted by Gittens (2009). It consists of 35 items and places 
each item on a 5-point Likert type scale pertaining to transformational leadership, to measure and identify transformational leadership behaviours with recognising five interrelated components for transformational leadership. The instructions of the instrument asked respondents to rate the listed transformational leadership behaviours of department heads. The respondents were asked to rate their agreement response with which each type of behaviour that was exhibited by the department head. The scale utilised was: 1) strongly disagree; 2) disagree; 3) neither agree nor disagree; 4) agree; and 5) strongly agree.

2- The individual survey items formed the five subscales (themes) of the Roueche et al. (1989) model of transformational leadership. There were seven items used to measure each of the five themes: vision, influence orientation, motivation orientation, people orientation and values orientation. For each respondent, the mean score for each of the items corresponding to a particular theme were calculated to form a score for each theme. The mean of all the item scores represented the aggregated or overall transformational leadership score by a respondent. This survey used one form (member form) to assess particular transformational leadership behaviours.

3- Demographic characteristics of college trainers were determined by a section in the questionnaire which consists of five demographic questions. This obtained a singleresponse to the variables of length of service, age, nationality, highest educational level obtained and name of the college where respondent works.

4- A job satisfaction measure - data on job satisfaction expressed by college trainers - was collected through the use of MCMJSS (Mohrman, et al., 1977). Intrinsic and extrinsic perceptions of job satisfaction (Sergiovanni, 1991) that are measured by the MCMJSS relate to the motivation-hygiene theory of Herzberg (1969).

\section{Instrument standardisation:}

This study employed an Arabic version of the modified questionnaires (MCLQ-III-dc) adopted by Gittens (2009) to match the purpose of this study.

The researcher tested the reliability of the questionnaire by redistributing it to a sample of 24 college trainers, outside of the initial study but drawn from the same population (i.e. TVTC college trainers in western region). This was sent out two weeks after the first distribution, and the score of Cronbach's alpha for the five dimensions was estimated to be as follows: vision (0.924), influence orientation (0.925), motivation orientation (0.934), and people orientation (0.918) and values orientation (0.936). The validity of the questionnaire was assessed by 12 trainer specialists in the field of technical education administration at TVTC.

To ensure the equivalence of meaning among the items and constructs between the Arabic and English versions of the MCMJSS, a rigorous translation process was used. This included forward and backward translations, subjective evaluations of the translated items and pilot testing with retaining both the form (language) and the meaning of the items as close to the original as possible, with priority to meaning equivalence. The back-translated items were then evaluated by a group of five linguists to ensure that the item meanings were equivalent in both the original English versions and the back-translated version. If differences in meaning were found between items, those items were again put through the forward and back-translation process, until the linguists were satisfied that there was substantial meaning equivalence. 
The Arabic version of the MCMJSS was then also pilot tested with a group of 10 trainer specialists in the field of technical and vocational training administration, to collect feedback about instrument content and usage. The feedback from the faculties emphasised that the instrument had both face and content validity. The Arabic version of the MCMJSS was then tested with a sample of 20 college trainer members outside of the study but drawn from the same population (i.e. TVTC colleges). Reliability coefficients for the MCMJSS were established for the two dimensions as follows: intrinsic job satisfaction (0.85) and extrinsic job satisfaction (0.83). These reliability estimates seemed consistent with previous research (Mohrman et.al., 1977). Reliability on the intrinsic scale ranged from 0.81 to 0.87 , and extrinsic reliability ranged from 0.77 to 0.82 . Although validity was not directly addressed by Mohrman et al. (1977), the scale has been widely accepted and frequently used by other researchers (Hardman, 1996; Profit, 1990). Based on the translation process and the reliability estimates, the Arabic-translated version of the MCMJSS seemed to be a valid and reliable measure for use within the population.

\section{Results:}

The first research question asked: What are the perceived leadership characteristics of TVTC colleges-western region department heads?

Table (2) shows that the total mean score of transformational behaviours (3.81) is high. Values, which refers to an ethical dimension of morally acceptable behaviour that uplifts followers, has the highest mean score at 3.89 , followed by people at 3.81 , while motivation is perceived as weakest of the transformational behaviours with a mean score of 3.75 . The other themes mean scores are vision at 3.78 and Influence orientation at 3.79).

Table (3) presents a summary of the respondents' means scores and standard deviations for each individual item. It can be seen from this table that the average means range between 3.59 for the item statement 10) "Provides faculty with incentives to excel", and 4.10 for item statement 1)"Applies consistent ethical standards in the department".

Table (2)

Leadership characteristics of department's heads In the TVTC colleges-western region

\begin{tabular}{c|c|c|c|c|c}
\hline \hline Factors & Mean & Std. Dev. & Percent & Rank & Level \\
\hline \hline Vision & 3.78 & 0.85 & 75.66 & 4 & High \\
\hline Influence & 3.79 & 0.86 & 75.82 & 3 & High \\
\hline Motivation & 3.75 & 0.87 & 75.08 & 5 & High \\
\hline People & 3.81 & 0.84 & 76.25 & 2 & High \\
\hline Values & 3.89 & 0.85 & 77.76 & 1 & High \\
\hline Total & $\mathbf{3 . 8 1}$ & $\mathbf{0 . 8 3}$ & $\mathbf{7 6 . 1 1}$ & - & High \\
\hline \hline
\end{tabular}

Table (3)

Descriptive Statistics for MCLQ-III-dc items

\begin{tabular}{c|c|l|c|c|c|c}
\hline $\begin{array}{c}\text { Leadership } \\
\text { Factors }\end{array}$ & $\begin{array}{c}\text { Item } \\
\text { no. }\end{array}$ & \multicolumn{1}{|c|}{ Item statement } & Mean & $\begin{array}{c}\text { Std. } \\
\text { Dev. }\end{array}$ & Rank & Level \\
\hline \hline Vision & 4 & Makes changes when appropriate & 3.77 & 1.01 & 4 & High \\
\hline & 6 & Is able to visualise a specific future for the department & 3.81 & 1.03 & 3 & High \\
\hline & 15 & Employs quick and ready insights & 3.74 & 1.09 & 5 & High \\
\hline & 20 & Is committed to innovative action to achieve goals & 3.60 & 1.03 & 7 & High \\
\hline
\end{tabular}


Table (3)

Descriptive Statistics for MCLQ-III-dc items

\begin{tabular}{|c|c|c|c|c|c|c|}
\hline $\begin{array}{l}\text { Leadership } \\
\text { Factors }\end{array}$ & $\begin{array}{l}\text { Item } \\
\text { no. }\end{array}$ & Item statement & Mean & $\begin{array}{l}\text { Std. } \\
\text { Dev. }\end{array}$ & Rank & Level \\
\hline & 23 & $\begin{array}{l}\text { Believes that he will be able to shape the future of } \\
\text { his department }\end{array}$ & 3.88 & 0.98 & 2 & High \\
\hline & 28 & Enables sharing in a vision of the future & 3.73 & 1.02 & 6 & High \\
\hline & 32 & Communicates a sense of vision to faculty & 3.95 & 0.91 & 1 & High \\
\hline \multirow[t]{7}{*}{ Influence } & 3 & Empowers faculty appropriately & 3.86 & 0.95 & 1 & High \\
\hline & 9 & Is open to influence & 3.83 & 1.04 & 3 & High \\
\hline & 11 & Exerts appropriate influence on faculty & 3.71 & 1.04 & 7 & High \\
\hline & 16 & Involves faculty appropriately in decision-making & 3.75 & 1.09 & 5 & High \\
\hline & 19 & Is visible to those he is attempting to influence & 3.84 & 1.04 & 2 & High \\
\hline & 22 & $\begin{array}{l}\text { Empowers faculty through tasking and } \\
\text { consideration of their needs }\end{array}$ & 3.81 & 1.06 & 4 & High \\
\hline & 25 & $\begin{array}{l}\text { Employs appropriate power to influence faculty } \\
\text { performance }\end{array}$ & 3.73 & 1.01 & 6 & High \\
\hline \multirow{7}{*}{ Motivation } & 2 & Inspires faculty in appropriate ways & 3.84 & 1.05 & 2 & High \\
\hline & 10 & Provides faculty with incentives to excel & 3.59 & 1.10 & 7 & High \\
\hline & 14 & $\begin{array}{l}\text { Motivates faculty through clarification of his } \\
\text { expectations }\end{array}$ & 3.67 & 1.04 & 6 & High \\
\hline & 24 & Motivates faculty to action & 3.80 & 1.00 & 3 & High \\
\hline & 30 & Motivates faculty to use their creative skills & 3.76 & 1.00 & 4 & High \\
\hline & 33 & Is able to galvanise the department to action & 3.87 & 0.94 & 1 & High \\
\hline & 35 & Stimulates change when needed & 3.74 & 1.01 & 5 & High \\
\hline \multirow[t]{7}{*}{ People } & 5 & Seeks faculty opinions & 3.98 & 1.01 & 1 & High \\
\hline & 8 & Accommodates faculty's individual needs & 3.71 & 0.99 & 6 & High \\
\hline & 12 & Understands faculty's values & 3.86 & 1.01 & 3 & High \\
\hline & 18 & Considers the needs of his faculty & 3.87 & 1.05 & 2 & High \\
\hline & 27 & Respects faculty's individual differences & 3.82 & 1.02 & 4 & High \\
\hline & 29 & Considers faculty's needs & 3.80 & 1.00 & 5 & High \\
\hline & 31 & Rewards faculty appropriately & 3.65 & 1.09 & 7 & High \\
\hline \multirow[t]{7}{*}{ Values } & 1 & Applies consistent ethical standards in the department & 4.10 & 0.89 & 1 & High \\
\hline & 7 & Encourages faculty's ethical development & 3.79 & 1.04 & 6 & High \\
\hline & 13 & Influences faculty through his personal behaviour & 3.81 & 1.07 & 5 & High \\
\hline & 17 & Conforms to a standard of what is right & 3.93 & 1.04 & 2 & High \\
\hline & 21 & Seeks to build an ethical environment & 3.92 & 1.02 & 4 & High \\
\hline & 26 & $\begin{array}{l}\text { Helps faculty conform to a standard of what is } \\
\text { right and good }\end{array}$ & 3.92 & 0.90 & 3 & High \\
\hline & 34 & Is a principled chair & 3.75 & 1.18 & 7 & High \\
\hline
\end{tabular}

Table 4 presents the means and standard deviations for trainers concerning intrinsic and extrinsic job satisfaction. The mean score for trainers overall job satisfaction is high 3.88 (SD 1.08). The mean score for trainers on intrinsic job satisfaction is 3.89 (SD 1.21), while it is 3.87 (SD 1.19) for extrinsic job satisfaction.

Table (4)

Descriptive statistics MCMJSS

\begin{tabular}{c|c|c|c}
\hline \hline & Intrinsic job satisfaction & Extrinsic job satisfaction & Overall job satisfaction \\
\hline \hline Mean & 3.89 & 3.87 & 3.88 \\
\hline Std. Dev. & 1.21 & 1.19 & 1.08 \\
\hline \hline
\end{tabular}


المجلة العببة للإدارة، مج 33، ع 2 - ديسمبر (كانون أول) 2013

Table 5 shows there are statistically significant differences (at $0.05 \%$ level of significance) in degrees of extrinsic job satisfaction according to different qualifications, but there are no significant differences in intrinsic job satisfaction and overall job satisfaction. However, the least significance differences (LSD) test for significant differences between the averages of job satisfaction according to the qualification (as in Table 6) shows significant differences in extrinsic job satisfaction at the level of significance $(0.05 \%)$ between Graduate and $\mathrm{PhD}$ for $\mathrm{PhD}$, and between Master and $\mathrm{PhD}$ for $\mathrm{PhD}$, with same results for overall job satisfaction.

Table (5)

Analysis of variance on the perceptions of trainers concerning overall, intrinsic and extrinsic job satisfaction - Qualification

\begin{tabular}{c|c|c|c|c|c|c|c}
\hline \hline Job satisfaction & Source of variance & SS & df & MS & F & Sig. & Sig. \\
\hline \hline Intrinsic job satisfaction & Between groups & 6.426 & 3 & 2.142 & 1.463 & 0.224 & N.S \\
\hline & Within groups & 516.904 & 353 & 1.464 & & & \\
\hline & Total & 523.330 & 356 & & & & \\
\hline Extrinsic job satisfaction & Between groups & 11.675 & 3 & 3.892 & 2.810 & 0.039 & 0.05 \\
\hline & Within groups & 488.880 & 353 & 1.385 & & & \\
\hline & Total & 500.555 & 356 & & & & \\
\hline Overall job satisfaction & Between groups & 8.787 & 3 & 2.929 & 2.529 & 0.057 & N.S \\
\hline & Within groups & 408.875 & 353 & 1.158 & & & \\
\hline & Total & 417.662 & 356 & & & & \\
\hline \hline
\end{tabular}

Table (6)

LSD test for significance between the averages

Of job satisfaction according to qualification

\begin{tabular}{c|c|c|c|c|c|c}
\hline \hline Job satisfaction & Qualification & Means & Diploma & Graduate & Master & PhD \\
\hline \hline & Diploma & 4.033 & -- & & & \\
\hline Extrinsic job satisfaction & Graduate & 3.807 & 0.226 & -- & & \\
\hline & Master & 3.729 & 0.304 & 0.078 & -- & \\
\hline & PhD & 4.379 & -0.346 & $-0.572^{*}$ & $-0.650^{*}$ & -- \\
\hline \multirow{4}{*}{ Overall job satisfaction } & Diploma & 4.008 & -- & & & \\
\cline { 2 - 8 } & Graduate & 3.838 & 0.170 & -- & & \\
\cline { 2 - 8 } & Master & 3.746 & 0.263 & 0.093 & -- & \\
\cline { 2 - 8 } & PhD & 4.327 & -0.318 & $-0.488^{*}$ & $-0.581^{*}$ & -- \\
\hline \hline
\end{tabular}

*Significant at 0.05

An examination of Table 7 shows significant differences in all degrees of job satisfaction, according to different ages at the $0.05 \%$ level of significance.

Table 8 also shows there are significant differences between the average degree of job satisfaction for intrinsic job satisfaction between 51 and above and less than 30 years, 30-40 years for 51 and above, and extrinsic job satisfaction between 51 and above and both less than 30 years, and 30-41 years, and 40-50 years, for 51 and above. In contrast, in overall job satisfaction, the significant differences are between 51 and above and less than 30 years, 3040 years for 51 and above, in the sense that job satisfaction for this age group (51 years and above) are the most satisfied of the remaining categories. 
Transformational Leadership and Job Satisfaction...

Table (7)

Analysis of variance on the perceptions

Of trainers concerning overall, intrinsic and extrinsic job satisfaction - Age

\begin{tabular}{c|c|c|c|c|c|c|c}
\hline \hline Job satisfaction & Source of variance & SS & df & MS & F & Sig. & \\
\hline \hline Intrinsic job satisfaction & Between groups & 11.474 & 3 & 3.825 & 2.638 & 0.050 & 0.05 \\
\hline & Within groups & 511.856 & 353 & 1.450 & & & \\
\hline & Total & 523.330 & 356 & & & & \\
\hline Extrinsic job satisfaction & Between groups & 13.542 & 3 & 4.514 & 3.272 & 0.021 & 0.05 \\
\hline & Within groups & 487.013 & 353 & 1.380 & & & \\
\hline & Total & 500.555 & 356 & & & & \\
\hline Overall job satisfaction & Between groups & 11.466 & 3 & 3.822 & 3.322 & 0.020 & 0.05 \\
\hline & Within groups & 406.196 & 353 & 1.151 & & & \\
\hline & Total & 417.662 & 356 & & & & \\
\hline \hline
\end{tabular}

Table (8)

LSD test for significance between the averages of job satisfaction according to age

\begin{tabular}{|c|c|c|c|c|c|c|}
\hline $\begin{array}{l}\text { Job } \\
\text { satisfaction }\end{array}$ & Age & Mean & $\begin{array}{c}\text { Less than } 30 \\
\text { years }\end{array}$ & $30-40$ years & 41-50 years & $\begin{array}{l}51 \text { and } \\
\text { above } \\
\text { years }\end{array}$ \\
\hline \multirow{4}{*}{$\begin{array}{l}\text { Intrinsic job } \\
\text { satisfaction }\end{array}$} & Less than 30 years & 3.770 & - & & & \multirow{4}{*}{ - } \\
\hline & 30-40 years & 3.781 & -0.011 & - & & \\
\hline & $41-50$ years & 4.066 & -0.296 & -0.285 & - & \\
\hline & 51 and above years & 4.289 & $-0.520 *$ & $-0.509^{*}$ & -0.224 & \\
\hline \multirow{4}{*}{$\begin{array}{l}\text { Extrinsic job } \\
\text { satisfaction }\end{array}$} & Less than 30 years & 3.675 & - & & & \multirow{4}{*}{ - } \\
\hline & $30-40$ years & 3.822 & -0.148 & - & & \\
\hline & $41-50$ years & 3.865 & -0.191 & -0.043 & - & \\
\hline & 51 and above years & 4.401 & $-0.727 *$ & $-0.579 *$ & $-0.536^{*}$ & \\
\hline \multirow{4}{*}{$\begin{array}{l}\text { Overall job } \\
\text { satisfaction }\end{array}$} & Less than 30 years & 3.722 & - & & & \\
\hline & $30-40$ years & 3.801 & -0.079 & - & & \\
\hline & $41-50$ years & 3.965 & -0.243 & -0.164 & - & \\
\hline & 51 and above years & 4.345 & $-0.623 *$ & $-0.544 *$ & -0.380 & \\
\hline
\end{tabular}

* Significant at 0.05

Table 9 depicts significant differences in degrees of overall job satisfaction according to different lengths of service at the $0.05 \%$ level of significance. It also shows statistically significant differences in degrees of extrinsic job satisfaction according to different lengths of service at the $0.01 \%$ level of significance. There are no significant differences in degrees of intrinsic job satisfaction according to different lengths of service.

Table 10 shows there are significant differences in job satisfaction from extrinsic factors of job satisfaction, and total job satisfaction among respondents with more than 30 years of service, those with 10-30 years of service and those with less than 10 years of service. These results indicate (?) that as the trainer's length of service increases, the level of trainer job satisfaction also increases. 
المجلة العربية للإدارة، مج 33، ع 2 - ديسمبر (كانون أول) 2013

Table (9)

Analysis of variance for the perceptions of trainers concerning overall, intrinsic and extrinsic job satisfaction - Length of service.

\begin{tabular}{c|c|c|c|c|c|c|c}
\hline \hline Job Satisfaction & Source of variance & SS & df & MS & F & Sig. & \\
\hline \hline \multirow{2}{*}{ Intrinsic } & Between groups & 5.214 & 2 & 2.607 & 1.781 & 0.170 & N.S \\
\cline { 2 - 8 } Job Satisfaction & Within groups & 518.117 & 354 & 1.464 & & & \\
\cline { 2 - 9 } & Total & 523.330 & 356 & & & & \\
\hline \multirow{2}{*}{ Extrinsic } & Between groups & 14.900 & 2 & 7.450 & 5.430 & 0.005 & 0.01 \\
\cline { 2 - 9 } Satisfaction & Within groups & 485.655 & 354 & 1.372 & & & \\
\cline { 2 - 9 } & Total & 500.555 & 356 & & & & \\
\cline { 2 - 8 } Overall & Between groups & 9.034 & 2 & 4.517 & 3.913 & 0.021 & 0.05 \\
\cline { 2 - 8 } Satisfaction & Within groups & 408.628 & 354 & 1.154 & & & \\
\cline { 2 - 8 } & Total & 417.662 & 356 & & & & \\
\hline \hline
\end{tabular}

Table (10)

LSD test for significance between the averages

Of job satisfaction according to length of service

\begin{tabular}{|c|c|c|c|c|c|}
\hline $\begin{array}{c}\text { Job } \\
\text { Satisfaction }\end{array}$ & Length of service & Mean & $\begin{array}{l}\text { Less than } \\
10 \text { years }\end{array}$ & $\begin{array}{l}\mathbf{1 0 - 3 0} \\
\text { years }\end{array}$ & $\begin{array}{c}\text { 30 years } \\
\text { and above }\end{array}$ \\
\hline \multirow{3}{*}{$\begin{array}{l}\text { Extrinsic job } \\
\text { satisfaction }\end{array}$} & Less than 10 years & 3.747 & & \multirow{3}{*}{$0 . \overline{486 *}$} & \\
\hline & $10-30$ years & 3.793 & -0.046 & & \\
\hline & 30 years and above & 4.279 & $-0.532^{*}$ & & \\
\hline \multirow{3}{*}{$\begin{array}{l}\text { Overall job } \\
\text { satisfaction }\end{array}$} & Less than 10 years & 3.811 & & \multirow{3}{*}{$0.412 *$} & \\
\hline & 10-30 years & 3.790 & 0.021 & & \\
\hline & 30 years and above & 4.202 & $-0.391 *$ & & \\
\hline
\end{tabular}

* Significant at 0.05

According to Table 11, there is insufficient evidence to show that a significant difference exists between trainers' perceptions concerning overall and extrinsic job satisfaction according to their nationality. Conversely, there is a statistically significant relationship at the $0.05 \%$ level of significance between trainers' perceptions of intrinsic job satisfaction and trainers' nationalities (two variables: Saudi and others) - other nationalities tend to be more satisfied than Saudi trainers.

Table (11)

Analysis of variance on the perceptions of trainers concerning overall, intrinsic and extrinsic job satisfaction - Nationality

\begin{tabular}{c||c|c|c|c|c}
\hline \hline Job satisfaction & Nationality & $\mathbf{n}=$ & Mean & Std. Dev. & t-values \\
\hline \hline \multirow{2}{*}{ Intrinsic job satisfaction } & Saudi & 275 & 3.82 & 1.20 & \multirow{2}{*}{$2.03^{*}$} \\
\cline { 2 - 5 } & Others & 82 & 4.13 & 1.22 & \multirow{2}{*}{0.919} \\
\hline \multirow{2}{*}{ Extrinsic job satisfaction } & Saudi & 275 & 3.84 & 1.17 & 1.23 \\
\cline { 2 - 5 } & Others & 82 & 3.97 & 1.08 & \multirow{2}{*}{0.998} \\
\hline \multirow{2}{*}{ Overall job satisfaction } & Saudi & 275 & 3.83 & 1.06 & \multirow{2}{*}{} \\
\cline { 2 - 5 } & Others & 82 & 4.05 & 1.06 & \\
\hline \hline
\end{tabular}

*t-value tabulated at Sig $0.05=1.96$

Table 12 identifies the significant associations between perceived transformational leadership behaviours, overall job satisfaction and demographic factors: 
1- Qualification is significantly and positively related to length of service, age and nationality.

2- Years employed is significantly and positively related to age.

3- Nationality is significantly and positively related to qualification and age, and conversely it is significantly and negatively related to length of service.

4- College of employment is significantly and negatively related to length of service.

5- Overall job satisfaction is significantly and positively related to transformational leadership.

6- Length of service and age are significantly and positively related to overall job satisfaction.

Thus, in general the previous data indicates that as trainers age, and the longer trainers hold their positions, the more likely they are to be satisfied. Overall job satisfaction is a positive influence on perceived transformational leadership. Thus, trainers are shown to be more satisfied in their current positions if they perceive their department heads to be transformational leaders. There is no significant relationship between demographic factors and perceived transformational leadership behaviours means that differences in demographic factors among respondents have no influence on perceived transformational leadership. The findings indicated that department heads perceived transformational leadership characteristics were positive influencers of Colleges trainers' job satisfaction. Results of this study support current literature, in that there is a significant and positive relationship between leadership behaviours and outcomes such as job satisfaction (Altman, 2002; Roberts, 2001; Evans, 1999; Lowe \& Kroeck 1996; Gasper 1992, Hollander \& Offermann 1990; Yammarino \& Bass, 1990; Bass \& Avolio 1990 \&Waldman, Bass \& Yammarino 1990).

Table (12)

Summary of the bivariate correlation matrix Of leadership, overall job satisfaction and demographic variables

\begin{tabular}{c|c|c|c|c|c|c|c}
\hline \hline & Qualification & $\begin{array}{c}\text { Length of } \\
\text { service }\end{array}$ & Age & Nationality & Colleges & $\begin{array}{c}\text { Job } \\
\text { satisfaction }\end{array}$ & $\begin{array}{c}\text { Transformational } \\
\text { leadership }\end{array}$ \\
\hline \hline Qualification & 1 & $.183^{* *}$ & $.370^{* *}$ & $.393^{* *}$ & 0.049 & 0.035 & 0.03 \\
\hline Length of service & & 1 & $.643^{* *}$ & $-.108^{*}$ & $-.142-* *$ & $.115^{*}$ & 0.062 \\
\hline Age & & & 1 & $.158^{* *}$ & $-.049-$ & $.155^{* *}$ & 0.087 \\
\hline Nationality & & & & 1 & $-.006-$ & 0.087 & 0.009 \\
\hline Colleges & & & & & 1 & 0.03 & $-.040-$ \\
\hline Job satisfaction & & & & & & 1 & $.337^{* *}$ \\
\hline $\begin{array}{c}\text { Transformational } \\
\text { leadership }\end{array}$ & & & & & & 1 \\
\hline \hline
\end{tabular}

**Correlation is significant at the 0.01 level (2-tailed)

*Correlation is significant at the 0.05 level (2-tailed)

Table 13 clarifies the Pearson correlation analysis between transformational leadership skills, and overall job satisfaction, extrinsic job satisfaction and intrinsic job satisfaction. The data analysed indicates a statistically significant relationship between overall job satisfaction, extrinsic job satisfaction and dimensions of transformational leadership style. The result of the correlation analysis between skills of transformational leadership dimensions scores and the extrinsic job satisfaction is $\mathrm{r}=0.408$, and between transformational leadership style scores and 
overall job satisfaction is $\mathrm{r}=0.337$. These indicate that the more prominent the characteristics of the dimensions of transformational leadership style, the more the degree of self-reported job satisfaction.

A greater degree of extrinsic job satisfaction was reported when the leadership behaviour fell within the motivation dimension $(\mathrm{r}=0.411)$. The result of the correlation analysis between transformational leadership dimensions scores and intrinsic job satisfaction is $r=0.203-$ this was statistically significant, but not as strongly correlated.

Table (13)

Pearson correlational analysis between transformational leadership dimensions And overall job satisfaction, extrinsic job satisfaction and intrinsic job satisfaction

\begin{tabular}{c|c|c}
\hline \hline Variable & Variable & r-value/job satisfaction \\
\hline \hline & Vision & $0.196^{* *}$ \\
\hline & Influence & $0.193^{* *}$ \\
\hline Intrinsic job satisfaction & Motivation & $0.210^{* *}$ \\
\hline & People & $0.198^{* *}$ \\
\hline & Values & $0.187^{* *}$ \\
\hline & Total & $\mathbf{0 . 2 0 3} * *$ \\
\hline & Vision & $0.390^{* *}$ \\
\hline & Influence & $0.406^{* *}$ \\
\hline Extrinsic job satisfaction & Motivation & $0.411^{* *}$ \\
\hline & People & $0.392^{* *}$ \\
\hline & Values & $0.381^{* *}$ \\
\hline & Total & $\mathbf{0 . 4 0 8} * *$ \\
\hline & Vision & $0.323^{* *}$ \\
\hline Overall job satisfaction & Influence & $0.330^{* *}$ \\
\hline & Motivation & $0.343^{* *}$ \\
\hline & People & $0.325^{* *}$ \\
\hline \hline & Values & $0.313^{* *}$ \\
\hline
\end{tabular}

**Pearson correlation coefficient tabulated at $0.01=0.128$

Table 14 presents the regression model, accounting for the most variation in total job satisfaction by individual factors of transformational leadership. Results of the multiple regression analysis replicate previous studies: Lowe \& Kroeck, 1996; Gasper, 1992; Hollander \& Offermann, 1990; Bass 1985; Bass, Waldman, Avolio \& Bebb, 1987; Waldman, Bass \& Yammarino, 1990). TVTC department heads perceived to have transformational leadership characteristics have positive relationships with trainers' job satisfaction.

The following summary identifies the amount of variation in trainers' job satisfaction accounted for by individual independent factors:

1- Vision factor explains $10 \%$ of the variation in college trainers' job satisfaction scores.

2- Influence factor explains $7 \%$ of the variation in college trainers' job satisfaction scores.

3- Motivation factor explains $7 \%$ of the variation in college trainers' job satisfaction scores.

4- Values factor explains $1 \%$ of the variation in college trainers' job satisfaction scores.

Department heads are perceived to demonstrate behaviours of transformational leadership frequently where they expresses enthusiasm, optimism, and confidence and encourages problem 
solving, critical thinking, and creativity and these behaviours and these perceived effects of transformational leadership factors (vision, influence and motivation) are significantly and positively related to overall job satisfaction. In this study, positive Beta scores of.028,.100,.360, and.058 signify that as trainers' perceptions of the level of transformational leadership behaviours increase, the level of trainers' job satisfaction also increases. In summary the perceived effects of (Vision) account for the biggest variation of trainers total job satisfaction (10\%), followed by (Influence) and (Motivation) each explained (7\%) of the variation in trainers total job satisfaction, the (Values) factor given almost none (1\%), while the perceived behaviours (People) did not account for any variation in employees total job satisfaction. As a result of their research involving 78 members of self-directed work teams, Butler, Cantrell, \& Flick (1999) reported that individualized support (a leadership dimension similar to the people orientation theme) and intellectual stimulation (a leadership dimension similar to the influence orientation theme) resulted in higher levels of job satisfaction. (See Table 14).

Table (14)

Regression model accounting for most variation In overall job satisfaction by individual factors

\begin{tabular}{c|c|c|c}
\hline \hline Factors & R Square Change & F Change & Beta \\
\hline \hline Vision & 0.104 & 41.365 & $.028^{*}$ \\
\hline Influence & 0.007 & 2.691 & $.100^{*}$ \\
\hline Motivation & 0.007 & 2.713 & $.360^{*}$ \\
\hline People & 0.000 & 0.051 & $.058^{*}$ \\
\hline Values & 0.001 & 0.316 & $-.112^{*}$ \\
\hline \hline
\end{tabular}

*Significant at 0.05

Data collected in this research study does not support a strong relationship between Department heads perceived transformational and trainers' job satisfaction. However, (People), and (Values) considered the least constructive leadership behaviours, were found to have neutral influence on trainers' job satisfaction. This weak correlations between Department heads perceived transformational behaviours and trainers' job satisfaction may not be related to how employees feel about their Department heads perceived transformational leadership behaviours. Researchers have investigated the reasons behind the job dissatisfaction. Ghiselli et al. (2001) reported that salary; benefit packages, working hours, family, and quality of life are reasons for satisfaction and/or dissatisfaction, other researcher reported the reasons as poor training (Lashley and Best, 2002).

Another reason why the results suggest that weak correlations between Department heads perceived transformational behaviours and trainers' job satisfaction may not be related to how employees feel about their Department heads perceived transformational leadership behaviours, may be due to that the lack of Perceived Organizational Support (POS). Job satisfaction is more likely related to Perceived Organizational Support (POS), many researchers discussed Motivational theories, which could be employed as a practical application for leaders to increase job satisfaction; Perceived Organizational Support, is increased when employees believe the organization considers their goals and values, demonstrates concern for them, helps when they have a problem, is concerned about their opinions, forgives honest mistakes, and will not take advantage of them (Rhoades \& Eisenberger, 2002). Job satisfaction maybe more likely related to retirement money, promotion, and job security, and alternative employment opportunities according to the motivational 
theory Goal Setting: Promotion goals are related to growth, advancement, and accomplishment; prevention goals are related to security, responsibility, and safety (Higgins, 1998). Short term, or proximal, goals help individuals to stay on track and help to maintain motivation; long term, or distal, goals can be overwhelming and actually reduce performance (Latham \& Seijts, 1999). Another reason why the results suggest that weak correlations between Department heads perceived transformational behaviors and trainers' job satisfaction maybe due to that the major causes of job dissatisfaction is related to the poor employment conditions (Hinkin and Tracey's, 2000). Other studies suggest causes such as inadequate human resources support (Taylor et al., 2001), age (i.e. youth) and job dissatisfaction related to pay, long hours, and boring work (Ghiselli et al., 2001), poor training (Lashley and Best, 2002).

\section{Conclusion:}

This study was undertaken because of the researcher's interest in investigating the aspects of the leadership styles of technical college department heads that affect college trainers' job satisfaction. The study shows that the mean scores of transformational leadership of department heads are, in general, perceived to be high. Thus, transformational leadership behaviours of department heads are perceived by college trainers as positive. The mean scores for transformational behaviours follows the same patterns and are consistent with the results of previous studies (Bass \& Avolio, 2000; Avolio, Jung, Sivasubramaniam \& Murry, 1995).

The highest mean scores for transformational themes are values orientation at 3.89, followed by people orientation at 3.81, while the lowest is motivation at 3.75. The higher ratings of the values and people orientation themes support the idea that ethics, trust, consistency and focusing on the trainers' needs are important in departmental leadership. The high ratings for the values orientation theme in the current study is similar to the findings from previous studies, which supports the theory that such behaviours are ideal for chairs, and that trainers expect chairs to demonstrate these ethical and moral behaviours in their leadership roles and to focus on individual needs. A review of the ratings for the various transformational leadership themes identified by Roueche et al. (1989) reveals that the highest ratings are for the people orientation and values orientation themes.

According to the highest ratings in the questionnaire, department heads in the TVTC colleges in the western region are perceived to frequently demonstrate moral and ethical behaviours of transformational leadership. Resulting evidence of this from this study is: "Seeks faculty opinions" at 3.92, "Considers the needs of his faculty" at 3.87, "Seeks to builds an ethical environment" at 3.92, "Applies consistent ethical standards in the department" at 4.10, and "Is a principled chair" at 3.75. Therefore, a need for leadership development training programmes and supporting the role of the department head as a leader by the TVTC.

The department heads may have not the sufficient power to "Provide faculty with incentives to excel" (3.59) and "Reward faculty appropriately" (3.65). Previous studies noted there is a lack of positional power afforded to the middle-level leader, and that heads of college departments have no effective managerial power to deal with staff under their control - they had insufficient authority or support from above in attempting to deal with the staff performance issues, and operate by inspiring or engineering consent (Hellawell \& Hancock, 2001; Smith, 2007).

This study's analysis supports a relationship between department heads' perceived 
transformational leadership and college trainers' job satisfaction. Three of the transformational leadership behaviours - vision, influence and motivation - influence trainers' job satisfaction and are positive indicators of this satisfaction. However, values and people, considered the least constructive leadership behaviours, are found to have neutral influence on college trainers' job satisfaction.

Results of this study support current literature, in that there is a strong and positive relationship between leadership behaviours and job satisfaction (Altman, 2002; Lowe \& Kroeck, 1996; Gasper, 1992; Hollander \& Offermann, 1990; Yammarino \& Bass, 1990; Bass \& Avolio, 1990a; Waldman, et al., 1990). Department heads perceived transformational leadership characteristics are positive influencers of college trainers' job satisfaction. Brown and Moshavi (2002) found that inspirational motivation (a leadership dimension similar to the vision theme) was correlated with faculty satisfaction, intellectual stimulation (a leadership dimension similar to the influence orientation theme) with faculty's willingness to expend extra effort, and idealised influence (a leadership dimension similar to the values orientation theme) with faculty satisfaction with supervision, perceptions of organisational effectiveness and willingness to expend extra effort.

Woods (2004) also found that inspirational motivation was correlated with the organisational culture measure of adaptability. Leary, Sullivan \& McCartney-Simon (1999) found a strong correlation between the consideration dimension of leadership (a leadership dimension similar to the people orientation theme) and extrinsic satisfaction factors for faculty. Socio-demographic factors influence perceived transformational leadership and job satisfaction of college trainers. In general, the analysed data in this study concluded that as trainers' age, and the longer the trainers hold their positions, the more likely they are to be satisfied. This may be due to the manipulation of privileges and incentives given to the trainer as their years employed increases, such as financial incentives, scholarships, and reductions in workload, outboard training and promotions.

\section{Recommendations for research:}

1- This quantitative case study captures a snapshot of leadership behaviours within TVTC colleges in the western region of Saudi Arabia at only a given point in time. An important value would be added to understanding the relationship between department heads transformational leadership behaviours and college trainers' job satisfaction through a longitudinal study of all TVTC colleges in Saudi Arabia, as comparisons of results could then be made between colleges.

2- From a historical perceptive, a longitudinal study could also capture the internal actions and external events that impact perceived leadership, job satisfaction and other organisational outcomes. Colleges of this potential research study would be to include performance indicators, organisational commitment and citizenship, students' achievements, and trainers' self-efficacy in the interactions between perceived leadership behaviours and job satisfaction. Understanding the relationship between perceived leadership behaviours and performance, and job satisfaction and performance would broaden the theory and its implications for colleges' organisational success.

3- This study found a significant relationship between several of the demographic variables and trainers' perceptions of their leaders' transformational leadership behaviours. Further investigation of individual factors could contribute to better interpretation and use of this survey data 


\section{Recommendations for practice:}

1- Based on the study data and current research, one might imply that leadership style is important in ensuring higher job satisfaction.

2- The study indicates that department heads should consider concentrating on their transformational leadership behaviours to increase the job satisfaction of their departmental trainers. Gronn (1997) explained that transformational leaders create learning opportunities for followers, and empower them to solve problems as a means of fostering leadership skills. The value of leadership at the individual level, as well as all levels of the organisation, is now more than ever being realised as an essential need (Tichy, 1997).

3- The study's results support a need for leadership training programmes for department heads to strengthen their transformational leadership behaviours and their impact on fostering greater job satisfaction. According to TVTC Annual Report (2008), there are no training programmes for department heads or leadership-related workshops/seminars. TVTC should offer additional training and leadership-related workshops/seminars on the components of an effective transformational leadership system and its impact on performance indicators - quality, organisational commitment and citizenship, students' achievements, trainers' self-efficacy, and job satisfaction - to assist department heads in developing a higher level of and competence in transformational leadership behaviours.

4- TVTC administration should emphasise the recruitment and assignment of department heads who demonstrate positive transformational leadership behaviours.

5- TVTC administration might consider hiring a system-wide leadership specialist to work with all levels of college trainers in the area of leadership development and organisational outcomes, and to prepare the future leaders. Mitchell, Clayton, Hedberg and Paine (2003) provided numerous examples of the creativity of leading vocational education teachers, and their capabilities around integration, innovation and clever assessment devices.

6- TVTC administration might also consider the appropriate delegation and empowerment of department head roles, in order to have the sufficient support to motivate the staff, control and reward their performance, and to be able to galvanise the department to action to play the prospected role of the vocational department chair as a transformational leader.

\section{Limitations:}

In this study, trainers' participation was voluntary and conducted at five technical colleges in western region of Saudi Arabia. These factors limit the possibility of generalising from the study findings - results can only be generalised to all trainers employed in western region of Saudi Arabia. Therefore, the findings should be interpreted with caution, since the respondents were colleges trainers from a particular province of Saudi Arabia and do not represent all colleges trainers in this country.

This study may serve as a foundation for future studies in different countries. It is recommended that this study be repeated in different countries and in different contexts in different colleges. The results of such studies can be very helpful for developing a new model of transformational leadership, with new techniques that can be implemented easily and successfully in a cross cultural context. Other variables not studied here may be more important than the ones chosen for this study.

The self-reporting format of this study's questionnaire also poses the problem of honesty in reporting attitude. Additionally, the rater, chosen at the college to complete the rater form, could bias the results. 


\section{References}

- Alban-Metcalfe, R.J. and B. Alimo-Metcalfe. (2000). "The transformational leadership questionnaire (TLQ-LGV): a convergent and discriminate validation study". Leadership \& Organization Development Journal, Vol. 21(No.6), pp. 280-96.

- Altman, M. (2002). Worker satisfaction and economic performance. Armonk, NY: M.E. Sharpe Publishers.

- Avolio, B. J. (2005). Leadership development in balance: Made/born. Mahwah, N.J.: Lawrence Erlbaum Associates.

- Avolio, B.J., Bass, B.M. (1988). 'Transformational leadership, charisma, and beyond', in J.G. Hunt, B.R. Bagliga,

- Avolio, B.; D. Jung; N. Sivasubramaniam and B. Murry. (1995). "Vital forces: Building highly developed teams by enhancing the shared leadership capacity of organizations", paper presented at 3rd Annual University of North Texas symposium on work teams, Dallas, TX.

- Avolio, B. J. and F. J. Yammarino (Eds.). (2002). Transformational and charismatic leadership: The road ahead. Oxford, UK: Elsevier Science, Ltd.

- Barling, J.; T. Weber and E. K. Kelloway. (1996). "Effects of transformational leadership training on attitudinal and financial outcomes: a field experiment", Journal of Applied Psychology, Vol. 81, pp. 827-32.

- Bass, B. M. (1985). Leadership and performance beyond expectations. New York: Free Press.

- Bass, B. M. and Others. (1987). Transformational leadership and the falling dominoes effect. Group \& Organizational Studies, 12 (1), pp. 73-87.

- Bass, B. M. and B. J. Avolio. (1990a). The implications of transactional and transformational leadership for individual, team, and organizational development. Research in Organizational Change and Development, 4, pp. 231-272.

- Bass, B. M. and B. J. Avolio. (1990b). Developing transformational leadership: 1992 and beyond. Journal of European Industrial Training, 14, pp. 21-27.

- Bass, B. M. (1990). From transactional to transformational leadership: Learning to share the vision. Organizational Dynamics, pp. 19-31.

- Bass, B. M. and B. J. Avolio. (2000). Platoon readiness as a function of leadership, platoon and company cultures: Final report. Washington, DC: US Army Research Institute for the Behavioural and Social Sciences.

- Bennis, W. and B. Nanus. (1985). Leaders: Strategies for Taking Charge, Harper Collins, New York, NY.

- Bogler, R. (2001). "The influence of leadership style on teacher job satisfaction", Educational Administration Quarterly, 37, 662-683.

- Bottery, M. (2001). Globalisation and the UK competition state: No room for transformational leadership in education? School Leadership and Management, 21(2), pp. 199-218.

- Brown, F. W. and D. Moshavi. (2002). Herding academic cats: Faculty reactions transformational and contingent reward leadership by department chairs. The Journal of Leadership Studies, Vol. 8, pp. 79-92. 
- Burke, W. W. (1988). Leadership Report. W. Warner Burke and Associates, Pelham, N.Y.

- Burns, J. M. (1978). Leadership. Harper and Row, New York, NY.

- Butler, J. R. And S. Cantrell and R. Flick. (1999). Transformation leadership behaviours, upward trust, and satisfaction in self-managed work teams. Organization Development, 17 (1), 13-25.

- Clover, W. H. and W. E. Rosenbach. (1986). Item reduction of the multi factor leadership questionnaire (working paper), US Air Force Academy, Colorado Springs, CO.

- Conger, J. A. and R. N. Kanungo. (1987). 'Towards a behavioural theory of charismatic leadership in organisational settings', Academy of Management Review, 12 (4): 637-647.

- Copa, G. H. and J. Plihal. (1996). General education and subject matter education components of the vocational teacher education program. In: N. K. Hartley and T. L. Wentling (Eds.), beyond tradition: Preparing the teachers of tomorrow's workforce, (pp. 91 - 112). Columbia, MO: University Council for Vocational Education.

- Czech, K. (2007). Communication and leadership: Faculty perceptions of the department chair. Retrieved from PsycINFO database.

- Falk, I. and T. Smith. (2003) Leadership in vocational education and training: Leadership by design, not by default. Adelaide: NCVER.

- Fowler, W. J. (1991). What are the characteristics of principals identified as effective by teachers? (Eric Document Reproduction Service No. ED 347695).

- Gallmeier, K. (1992). The effectiveness of principal leadership style on teacher motivation. (Eric Document Reproduction Service No. ED 354 491).

- Gasper, J. M. (1992). Transformational leadership: An integrative review of the literature, (Doctoral dissertation, Western Michigan University, 1992). Dissertation Abstracts International, 53 (08A), 2619.

- Ghiselli, R. F.; J. La Lopa and B. Bai. (2001). "Job satisfaction, life satisfaction and turnover intend among food service managers", Cornell Hotel and Restaurant Administration Quarterly, April.

- Gittens, B. E. (2009). Perceptions of the applicability of transformational leadership behaviour to the leader role of academic department chairs: A study of selected universities in Virginia (Doctoral dissertation, The George Washington University, 2009). Dissertation Abstracts International.

- Gmelch, W. H. And V. D. Miskin. (2004). Chairing an academic department. Madison, WI: Atwood Publishing.

- Griffith, J. (2004). Relation of principal transformational leadership to school staff job satisfaction, staff turnover, and school performance. Journal of Educational Administration, 42 (3), 333-356.

- Gronn, P. (1997). Leading for learning: Organizational transformation and the formation of leaders. Journal of Management Development, Vol. 16 (No.4) ,pp. 274-283.

- Gunter, H. (2001) Leaders and Leadership in Education, London: Paul Chapman Publishing.

- Hall, V. (1994). Making a difference: women head teacher's contribution to schools as learning institutions. (Eric Document Reproduction Service No. ED 376 579).

- Hardman, T. M. (1996). A study of job satisfaction of female public school administrators in West Virginia (Unpublished doctoral dissertation, West Virginia University, Morgantown, WV). Dissertation Abstracts International. 
- Hay, I. (2006). Transformational leadership: Characteristics and criticisms. E-Journal of Organizational Learning and Leadership, 5 (2). Retrieved from:

http://weleadinlearning.org/transformationalleadership.htm

- Hellawell, D. N. Hancock. (2001) A case study of the changing role of the academic middle manager in higher education: between hierarchical control and collegiality?', Research Papers in Education, Vol. 16, No. 2, pp. 183-197.

- Herzberg, F. (1969). Work and the nature of man. Cleveland, OH: World.

- Higgins, E. T. (1998). Promotion and prevention: Regulatory focus as a motivational principle. In M. P. Zanna (Ed.), Advances in experimental social psychology, Vol. 30, pp. 1-46. NY: Academic press.

- Hinkin, T. And J. B. Tracey. (2000). "The cost of turnover", Cornell Hotel and Restaurant Administration Quarterly, Vol. 41, No. 3.

- Holdaway, E. A. (1978). Facet and overall satisfaction of teachers. Educational Administration Quarterly, 14, 30-47.

- Hollander, E. P. and L. R. Offermann. (1990). Relational features of organizational leadership and followership. In K.E. Clark \& M. B. Clark (Eds.), Measures of leadership (pp. 83-97), West Orange, N.J.: Leadership Library of America.

- House, R. J.; W. D. Spangler and Woycke, J. (1991). Personality and charisma in the U.S. Presidency: A psychological theory of leadership effectiveness. Administrative Science Quarterly. 36. 364-396.

- Hoy, W. K.; C. G. Miskel. (2001). Educational administration: Theory, research, and practice. Boston, MA: McGraw-Hill.

- Jones, D. (2006). State shortfalls projected to continue despite economic gains: Long term prospects for higher education no brighter. The Secretary of Education's Commission on the Future of Higher Education. Retrieved on January 11, 2010 from: http://www.ed.gov/about/bdscomm/list/hiedfuture/reports/jones.pdf

- Kezar, A. J.; R. Carducci and M. Contreras-McGavin. (2006). Rethinking the "L" word in higher education: The revolution of research on leadership. San Francisco, CA: Association for the Study of Higher Education.

- Kouzes, J. M. and B. Z. Posner. (1988). The Leadership Challenge. $6^{\text {th }}$ ed. Jossey Bass, San Francisco, CA.

- Krill, T. L.; R. I. Carter and D.L. Williams. (1997). "An exploration of the leadership practice enabling others to act: A case study", Journal of Agricultural Education, 38(4), pp. 42-49.

- Lashley, C. And W. Best. (2002). "Employee induction in licensed retail organisations", International Journal of Contemporary Hospitality Management, Vol. 14, No.1, pp.6-13.

- Latham, G. P. and G. H. Seijts. (1999). "The effects of proximal and distal goals on performance on a moderately complex task", Journal of Organizational Behavior, 20(4), 421.

- Leary, P. A.; M. E. Sullivan and D. R. McCartney-Simon. (1999). "The relationship of leadership styles of selected West Virginia deans and department chairs to job satisfaction of departmental faculty members", National Forum of Education Administration and Supervision Journal, 15 E. 
- Leithwood, K. And D. Jantzi. (1999). Transformational school leadership effects: A replication. School Effectiveness and School Improvement, 10 (4), pp. 451-479.

- Leithwood, K.; D. Jantzi and R. Steinbach. (2000). "Transformational leadership as a place to begin", In: Changing leadership for changing times, (pp. 21-39). Philadelphia, PA: Open University Press.

- Lipham, J. (1981). The relationship of decision involvement and principal's leadership to teacher job satisfaction in selected schools. (Eric Document Reproduction Service No. ED 207 129).

- Lowe, K. B. and G. Kroeck, (1996). "Effectiveness correlates of transformational and transactional leadership: A meta-analytic review of the MLQ literature", Leadership Quarterly, 7 (3), pp. 385426.

- Luthans, F. And B. J. Avolio. (2003). "Authentic leadership: A positive developmental approach", In: K. S. Cameron, J. E. Dutton \& R. E. Quinn (Eds.). Positive Organizational Scholarship. San Francisco: Barrett-Koehler, pp. 241-261.

- Marks, H. M. And S. M. Printy. (2003). Principal leadership and school performance: An integration of transformational and instructional leadership. Educational Administration Quarterly, 39, (3), pp. 370-379.

- Miller, C. and C. Oldham. (2006). Setting the context. The Secretary of Education's Commission on the Future of Higher Education. Retrieved on January 07, 2010, from: http://www.ed.gov/about/bdscomm/list/hiedfuture/reports/miller-oldham.pdf

- Misener, T. R.; K. S.Haddock; J. U. Gleaton and R. Ajamieh. (1996). "Toward an international measure of job satisfaction", Nursing Research, Vol. 45, pp. 87-91.

- Mitchell, J.; B. Clayton; J. Hedberg and N. Paine. (2003). Emerging futures: Innovation in teaching and learning in VET. Melbourne: ANTA.

- Mohrman, A. M. and Others. (1977). An assessment of a structural task approach to organizational development in a school system. Washington, DC: National Institute of Education.

- Profit, A. C. (1990). The relationship between locus of control and job satisfaction of Appalachian principals. [CD ROM] Abstract from: Proquest file: Dissertation Abstracts International, 9029346.

- Rhoades, L. And R. Eisenberger. (2002). Perceived organizational support: A review of the literature. Journal of Applied Psychology, 87, (4), 698.

- Roberts, W. (2001). It takes more than a carrot and a stick. New York: Andres McMeel.

- Roueche, J.; G. A. III Baker and R. R. Rose. (1989). Shared vision: Transformational leadership in American community colleges. Washington, D.C.: American Association of Community and Junior Colleges.

- Roush, P. E. (1992)." The Myers-Briggs type indicator, subordinate feedback, and perceptions of leadership effectiveness", In: K. E. Clark; M. B. Clark and D. P. Campbell, (Eds). Impact of Leadership, Centre for Creative Leadership, Greensboro, NC, pp. 529-43.

- Sashkin, M. and W.W. Burke. (1990). Understanding and assessing organizational leadership. In; Clark, K.E. and M. B. Clark. (Eds). Measures of Leadership, Leadership Library of America, West Orange, N.J., pp. 297-326.

- Sergiovanni, T. J. (1991). The principalship: A reflective practice perspective. 2nd ed. New York, NY: Simon and Schuster. 
- Smith, R. (2007). "On being a university head of department". Management in Education, Vol. 21, No. 1, pp. 4-7.

- Stogdill, R. M. (1974). Handbook of leadership. New York, NY: Appleton-Century- Crofts.

- Taylor, R.; D. Davies and L. Savery. (2001). "The role of appraisal and training in reducing staff turnover in the Western Australian accommodation industry", Management Research News, Vol. 24, No.10/11, pp.56-7.

- Tichy, N. M. (1997). The leadership engine. New York, NY: Harper Collins Publishers, Incorporated.

- Tichy, N. M. and M. Devanna. (1990). The transformational leader. New York: Wiley Publishing.

- TVTC Annual Report. (2010). The Saudi Technical and Vocational Training Corporation Annual Report, 2008. Retrieved on January 28, 2010 from TVTC website: http://www.tvtc.gov.sa/Downloads/Reports/annual\%20report.pdf

- Waldman, D.A.; B. M. Bass and F. J. Yammarino. (1990). "Adding to contingent-reward behavior: The augmenting effect of charismatic leadership", Group and Organizational Studies, 15, pp. 381-394.

- Wellman, J. V. (2006). Costs, prices and affordability: The Secretary of Education's Commission on the Future of Higher Education. Retrieved on January 11, 2010, from; http://www.ed.gov/about/bdscomm/list/hiedfuture/reports/wellman.pdf

- Wergin, J. L. (2004). Leadership in place. The Department Chair, 14, (4). Bolton, MA: Anker Publishing Company, Inc.

- Whitsett, G. (2007). Perceptions of leadership styles of department chairs. Retrieved November 11, 2009 from: PsycINFO database.

- Woods, R. (2004). The effects of transformational leadership, trust, and tolerance of ambiguity on organizational culture in higher education. Dissertation Abstract International (University Microfilms No. 3146727).

- Yammarino, F. J. And B. M. Bass. (1990). Transformational leadership and multiple levels of analysis. Human Relations, 43, (10), pp. 975-995.

- Yukl, G. (2002). Leadership in organizations. Upper Saddle River, New Jersey: Prentice-Hall. 
المجلة العربية للإدارة، مج 33، ع 2 - ديسمبر (كانون أول) 2013

\section{Appendix A}

Trainer Opinion Survey-Sample Multifactor College Leadership Questionnaire IIIDepartment Chair Version (MCLQ-III-dc) Items about the leadership behaviours of the department head/supervisor

The following statements concern how you perceive the leadership of the department head where you work. Please indicate the extent of your agreement or disagreement with the frequency of each statement expressing the behaviours of your department head as a transformational leader by circling a number from 1 to 5 . Please do not put your name on this questionnaire.

\begin{tabular}{|c|c|c|c|c|c|c|c|c|c|}
\hline \multicolumn{2}{|c|}{ Not at all } & Once in a while & Sometimes & Fairly often & \multicolumn{5}{|c|}{ Frequently, } \\
\hline & & & & & \multicolumn{5}{|c|}{ if not always } \\
\hline & 1 & 2 & 3 & 4 & \multicolumn{5}{|c|}{5} \\
\hline Item & \multicolumn{4}{|c|}{ Item Statement } & 1 & 2 & 3 & 4 & 5 \\
\hline 1 & \multicolumn{4}{|c|}{ applies consistent ethical standards to the job } & & & & & \\
\hline 2 & \multicolumn{4}{|c|}{ inspires faculty in appropriate ways } & & & & & \\
\hline 3 & \multicolumn{4}{|c|}{ empowers faculty appropriately } & & & & & \\
\hline 4 & \multicolumn{4}{|c|}{ makes changes when appropriate } & & & & & \\
\hline 5 & \multicolumn{4}{|c|}{ seeks opinions from faculty } & & & & & \\
\hline 6 & \multicolumn{4}{|c|}{ is able to visualize a specific future for the organization } & & & & & \\
\hline 7 & \multicolumn{4}{|c|}{ encourages ethical development of faculty } & & & & & \\
\hline 8 & \multicolumn{4}{|c|}{ accommodates individual needs of faculty } & & & & & \\
\hline 9 & \multicolumn{4}{|c|}{ is open to influence of faculty } & & & & & \\
\hline 10 & \multicolumn{4}{|c|}{ provides faculty with incentives to excel } & & & & & \\
\hline 11 & \multicolumn{4}{|c|}{ exerts appropriate influence on faculty } & & & & & \\
\hline 12 & \multicolumn{4}{|c|}{ understands the values of faculty } & & & & & \\
\hline 13 & \multicolumn{4}{|c|}{ influences faculty through personal behaviour } & & & & & \\
\hline 14 & \multicolumn{4}{|c|}{ motivates faculty through clarification of expectations } & & & & & \\
\hline 15 & \multicolumn{4}{|c|}{ employs quick and ready insights } & & & & & \\
\hline 16 & \multicolumn{4}{|c|}{ involves faculty appropriately in decision making } & & & & & \\
\hline 17 & \multicolumn{4}{|c|}{ conforms to a standard of what is right } & & & & & \\
\hline 18 & \multicolumn{4}{|c|}{ considers the needs of faculty } & & & & & \\
\hline 19 & \multicolumn{4}{|c|}{ is visible to those they are attempting to influence } & & & & & \\
\hline 20 & \multicolumn{4}{|c|}{ is committed to innovative action to achieve goals } & & & & & \\
\hline 21 & \multicolumn{4}{|c|}{ seeks to build an ethical environment } & & & & & \\
\hline 22 & \multicolumn{4}{|c|}{ empowers faculty through tasking and consideration of faculty needs } & & & & & \\
\hline 23 & \multicolumn{4}{|c|}{ believes that they will be able to shape the future of this department } & & & & & \\
\hline 24 & \multicolumn{4}{|c|}{ motivates faculty to action } & & & & & \\
\hline
\end{tabular}


Transformational Leadership and Job Satisfaction...

\begin{tabular}{c|l|l|l|l|l|l}
\hline \hline Item & \multicolumn{1}{|c|}{ Item Statement } & $\mathbf{1}$ & $\mathbf{2}$ & $\mathbf{3}$ & $\mathbf{4}$ & $\mathbf{5}$ \\
\hline \hline 25 & employs appropriate power to influence faculty's performance & & & & & \\
\hline 26 & helps faculty to conform to a standard of what is right and good & & & & & \\
\hline 27 & respects faculty's individual differences & & & & & \\
\hline 28 & enables faculty to share in a vision of the future & & & & \\
\hline 29 & considers faculty's needs & & & & \\
\hline 30 & motivates faculty to use their creative skills & & & & \\
\hline 31 & rewards faculty appropriately & & & & \\
\hline 32 & communicates a sense of mission to faculty & & & & \\
\hline 33 & is able to galvanize faculty to action & & & & \\
\hline 34 & is a principled leader & & & & & \\
\hline 35 & stimulates change when needed & & & & \\
\hline \hline
\end{tabular}

\section{Appendix B}

\section{JOB SATISFACTION SCALE}

Indicate your level of satisfaction with various facets of your job by circling a number on the six point scale after each of the statements.

\begin{tabular}{|c|c|c|c|c|c|}
\hline & Items & 1 & 2 & 4 & 56 \\
\hline 1 & The feeling of self-esteem or self-respect you get from being in your job & & & & \\
\hline 2 & The opportunity for personal growth and development in your job & & & & \\
\hline 3 & The feeling of worthwhile accomplishment in your job & & & & \\
\hline 4 & $\begin{array}{l}\text { Your present job when you consider the expectations you had when you took the } \\
\text { job }\end{array}$ & & & & \\
\hline 5 & The amount of respect and fair treatment you receive from your superiors & & & & \\
\hline 6 & The feeling of being informed in your job & & & & \\
\hline 7 & The amount of supervision you receive & & & & \\
\hline 8 & $\begin{array}{l}\text { The opportunity for participation in the determination of methods, procedures, and } \\
\text { goals }\end{array}$ & & & & \\
\hline
\end{tabular}

